\title{
MEMBELAJARKAN ORANGTUA MENJADI PENDAMPING AKTIVITAS BELAJAR DI RUMAH BAGI ANAKNYA SAAT PANDEMI COVID 19
}

\author{
Haryanto; Anik Ghufron; Ali Muhtadi; Monika Sidabutar* \\ Fakultas Ilmu Pendidikan, Universitas Negeri Yogyakarta \\ e-mail: monika.sidabutar@uny.ac.id
}

\begin{abstract}
Abstrak
Kegiatan PPM ini bertujuan untuk: 1) Memberikan pelatihan kepada orangtua tentang cara meningkatkan kemampuan sebagai pendamping aktivitas belajar di rumah bagi anaknya. 2) Meningkatkan mutu kinerja orangtua dalam melaksanakan pendampingan aktivitas belajar di rumah bagi anaknya. Kegiatan PPM ini dilaksanakan di Sekolah Dasar Gantiwarno kecamatan Gantiwarno dengan subyek sebanyak 37 peserta yang terdiri dari orangtua TK dan SD. Metode yang digunakan ceramah, diskusi, dan simulasi/praktek. Metode ceramah dan diskusi digunakan untuk menyampaikan materi dan memahamkan peserta tentang pentingnya peranan orangtua dalam mendampingi kegiatan belajar anak di rumah. Metode praktek/simulasi, digunakan untuk memberikan kesempatan kepada peserta untuk merancang aktifitas pendampingan yang dapat membantu anak belajar lebih optimal di rumah. Hasil kegiatan PPM menunjukkan bahwa: 1) Pengetahuan dan keterampilan peserta tentang bagaimana mendampingi aktifitas belajar anak di rumah meningkat. 2) Kegiatan pelatihan ini dinilai telah mampu memberikan kontribusi nyata terhadap peningkatan kemampuan orangtua dalam mendampingi aktiftias anak belajar di rumah. 3) Dihasilkannya tabel rancangan aktifitas pendampingan yang siap diterapkan oleh orangtua di rumah.
\end{abstract}

Kata Kunci: orangtua siswa, pendampingan aktifitas belajar anak

\section{EDUCATING PARENTS TO BE CHILDREN'S ASSISTANCE IN LEARNING ACTIVITY AT HOME DURING THE COVID-19 PANDEMIC}

\begin{abstract}
This community service (PPM) activity aimed to: 1) Provide training for parents on how to improve their ability to assist their children in learning activities at home. 2) Improve the quality of parental performance in carrying out assistance in learning activities at home for their children. This community service (PPM) activity was carried out at the Gantiwarno Elementary School, Gantiwarno sub-district with 37 participants consists of students' parents from kindergartens and elementary schools. The methods used are lectures, discussions, and simulation / practice. The lecture and discussion methods are used to convey and explain the material to participants about the importance of their role as parents in assisting children's learning activities at home. The practice / simulation method is used to provide opportunities for participants to design assistance activities that can help children to study optimally at home. The results of this community service (PPM) activities are: 1) participants' knowledge and skills improvement on how to assist children in learning activities at home. 2) This training activity is considered to have been able to make a real contribution to improving the ability of parents in assisting children's learning activities at home. 3) Produce a table of assisting activity designs that are ready to be implemented by parents at home.
\end{abstract}

Keywords: parents, assisting children's learning activities

\section{PENDAHULUAN}

\section{Analisis Situasi}

Orangtua merupakan pihak pertama dan utama bagi pendidikan anak-anaknya. Orangtua adalah figur utama bagi anak-anaknya. Orangtua merupakan teladan dan panutan bagi anak-anaknya. Dengan adanya berbagai peran orangtua terhadap pendidikan anak-anaknya maka orangtua memiliki kontribusi yang sangat besar bagi tumbuhkembang anak dan seharusnya orangtua menjadi guru, pendidik, dan pengasuh bagi anak-anaknya. Dalam realitanya, tidak semua orangtua memiliki kemampuan dan berperanan sebagai guru/pendidik/pengasuh bagi anak-anaknya. Mengapa demikian? Salah satu alasannya, orangtua merasa tidak memiliki latar belakang pendidikan dalam mengasuh dan mendidik anak. Kebanyakan di antara mereka menyerahkan urusan pendidikan anak ke pihak sekolah atau guru.

Perilaku sebagian orangtua yang menyerahkan urusan pendidikan anak-anaknya kepada pihak sekolah atau guru itu 
sesungguhnya kurang tepat. Orangtua seharusnya yang mendidik dan mengasuh anakanaknya. Sekolah atau guru hanyalah sebagai pihak kedua (yang membantu orangtua) dalam mendidik anak-anak. Apabila perilaku orangtua masih seperti itu dan mereka tidak mau belajar tentang cara-cara membelajarkan atau mengasuh anak-anaknya maka pada suatu saat mereka akan mengalami permasalahan ketika sekolah atau guru menghendaki anak harus belajar di rumah. Misalnya, pada saat ini terjadi pandemik wabah Covid 19 yang mewajibkan anak-anak belajar di rumah. Ada kesan keterpaksaan orangtua yang harus menjadi "guru" di rumah sebagai akibat anak-anaknya harus belajar on-line atau mandiri di rumah.

Ada keluhan lain terkait guru TK (taman kanak-kanak) memberi panduan berupa tema selama seminggu dan orangtua diminta memandu anak-anaknya bermain dan belajar sendiri dalam rangka pengembangan 6 aspek perkembangan. Setiap hari mereka mengirim video (meski tidak diminta) kepada guru tentang bagaimana orangtua membelajarkan anak-anaknya. Di sini timbul masalah karena ada beberapa kasus orangtua memaksakan kehendak kepada anak-anaknya untuk belajar dengan cara mereka (orangtua). Oleh sebab itu orangtua perlu diedukasi, bagaimana supaya dapat menjadi "guru" dadakan yang baik.

\section{Pendidikan dan Pengasuhan Anak}

Pendidikan dan pengasuhan anak merupakan kegiatan membantu tumbuh kembang anak secara optimal, terutama yang berkaitan dengan aspek-aspek non fisik. Direktur Pembinaan Pendidikan Anak Usia Dini (2017) mengatakan pendidikan dan pengasuhan anak merupakan proses pengembangan potensi anak yang mencakup nilai-nilai agama dan moral, fisik-motorik, kognitif, bahasa, sosial-emosional, dan seni yang dilakukan oleh guru dan orangtua di lembaga pendidikan, baik informal, formal, maupun non formal.

Pendidikan dan pengasuhan merupakan salah satu hak anak yang harus dipenuhi agar anak tumbuh dan berkembang secara optimal. Pertumbuhan adalah perubahan pada tubuh anak dalam jumlah atau besaran seperti: berat badan, tinggi badan dan lingkar kepala. Perkembangan adalah perubahan perilaku dan kemampuan anak dalam berbagai aspek seperti nilai agama dan moral, bahasa, kognitif, fisik motorik, sosial emosional dan seni.

Setiap satuan pendidikan memiliki kekhasan model pendidikan yang dilakukan. Misalnya, di PAUD dilakukan melalui kegiatan main, di mana anak memperoleh pengetahuan melalui kegiatan mainnya. Pengasuhan dilakukan secara bersama-sama antara guru, orangtua dan masyarakat. Di sekolah dasar dan sekolah menengah dilakukan melalui kegiatan pembelajaran secara mandiri dengan bimbingan guru.

\section{Peran Orangtua dalam Mendidik dan Mengasuh Anak}

Orangtua merupakan merupakan pihak utama dalam mendidik dan mengasuh anakanak. Pada diri mereka, pendidikan anak berlangsung dan berhasil. Tanpa kehadiran orangtua dalam kegiatan pendidikan dan pengasuhan anak niscaya tumbuhkembang anak akan kurang optimal. Apa yang harus diperankan orangtua dalam mendidik dan mengasuh anak-anaknya? Salah satu peran yang utama adalah menjadi guru bagi anakanaknya, terutama di saat anak-anak ada di rumah. Orangtualah yang akan memberi didikan dan asuhan bagi anak-anaknya.

Orangtua dapat dipastikan, selalu berharap agar anaknya menjadi orang yang saleh (baik). Tetapi perwujudan menjadi anak saleh ini kadangkala kurang dipahami oleh orangtua, sehingga apa yang menjadi harapannya bukan tidak mungkin justru mengecewakan. Aba Firdaus Al-Halwani (1996) menyatakan bahwa untuk mewujudkan anak yang saleh, sebagai orangtua harus mendidik anaknya dengan sentuhan penuh kelembutan, halus tanpa ancaman dan tanpa tekanan. Dalam beberapa kasus masih dijumpai adanya orangtua yang dalam mendidik anaknya justru dilakukan dengan kekerasan dan pemaksaan. Hal ini biasanya sering terjadi pada keluarga yang boken home. 
Imam Musbikin (2006) menyatakan bahwa mendidik anak dalam keluarga setidaknya harus mempethatikan tiga hal, pertama, untuk menumbuhkan prestasi belajar yang baik orangtua perlu menciptakan situasi yang dapat meningkatkan minat baca/belajar anak. Kedua, orangtua harus menjadi pola anutan atau model yang layak ditiru anaknya dalam segala perkatan, sikap, gerak, dan perbuatan baik secara langsung maupun tidak langsung. Ketiga, kasih sayang orangtua merupakan modal utama mengembangkan taraf intelegensi anak. Anak yang kurang mendapatkan kasih sayang akan berpengaruh terhadap petrkembangan taraf intelegensinya, bahkan akan berpengaruh terhadapo perkembangan kepribadiannya.

Apa yang harus dilakukan orangtua sebagai guru bagi anak-anaknya? Cara yang bisa dilakukan agar orangtua bisa berperanan sebagai guru bagi anak-anaknya adalah menguasai sejumlah kompetensi guru profesional pada umumnya, terutama kompetensi pedagogik. Dengan menguasai sejumlah kemampuan yang merupakan kompetensi guru profesional maka orangtua akan mampu melaksanakan tugas-tugas sebagai seorang guru.

Beberapa kemampuan pedagogik yang dapat dikuasai orangtua sebagai guru, sebagai berikut: (i) Memahami peserta didik secara mendalam yang meliputi memahami peserta didik dengan memanfaatkan prinsip-prinsip perkembangan kognitif, prinsip-prinsip kepribadian, dan mengidentifikasi bekal ajar awal peserta didik. (ii) Merancang pembelajaran,termasuk memahami landasan pendidikan untuk kepentingan pembelajaran yang meliputi memahmi landasan pendidikan, menerapkan teori belajar dan pembelajaran, menentukan strategi pembelajaran berdasarkan karakteristik peserta didik, kompetensi yang ingin dicapai, dan materi ajar, serta menyusun rancangan pembelajaran berdasarkan strategi yang dipilih. (iii) Melaksanakan pembelajaran yang meliputi menata latar (setting) pembelajaran dan melaksanakan pembelajaran yang kondusif. (iv) Merancang dan melaksanakan evaluasi pembelajaran yang meliputi merancang dan melaksanakan evaluasi (assessment) proses dan hasil belajar secara berkesinambungan dengan berbagai metode, menganalisis hasil evaluasi proses dan hasil belajar untuk menentukan tingkat ketuntasan belajar (mastery level), dan memanfaatkan hasil penilaian pembelajaran untuk perbaikan kualitas program pembelajaran secara umum. (v) Mengembangkan peserta didik untuk mengaktualisasikan berbagai potensinya meliputi memfasilitasi peserta didik untuk pengembangan berbagai potensi akademik, dan memfasilitasi peserta didik untuk mengembangkan berbagai potensi nonakademik.

Berdasarkan hasil analisis situasi yang telah dipaparkan, maka permasalahan yang dihadapi oleh sasaran kegiatan ini dapat dirumuskan sebagai berikut: (i) Orangtua sebagai figur, pihak utama, dan teladan bagi anaknya seharusnya mampu mendidik, mengasuh, dan menjadi pendamping bagi anaknya, tetapi belum semua orangtua mampu berperanan sebagai pendamping aktivitas belajar yang baik bagi anak di rumah. (ii) Banyak cara yang telah dilakukan oleh para pengambil kebijakan dan pakar untuk membelajarkan orangtua sebagai pengasuh dan pendidik bagi anaknya, terutama sebagai pendamping aktivitas belajar di rumah, tetapi belum banyak dilakukan oleh orangtua.

\section{METODE}

\section{Khalayak Sasaran}

Khalayak sasaran yang terlibat dalam kegiatan ini adalah perwakilan dari para orangtua anak-anak PAUD, TK, dan SD kelas rendah di Kecamatan Ganti Warno Kabupaten Klaten. Tim pengabdi menentukan sejumlah kurang lebih 30 orangtua PAUD, TK dan SD kelas rendah untuk dilatih menjadi pendamping aktivitas belajar di rumah bagi anaknya.

\section{Metode Kegiatan}

Berdasarkan pada berbagai hal yang telah dikemukakan sebelumnya, maka pelaksanaan program ini akan dilakukan dengan metode kegiatan berikut ini: 
(i) Pelatihan dan Penyuluhan

Digunakan untuk memberikan pemahaman kepada peserta pelatihan dalam hal peningkatan meningkat kemampuan peserta pelatihan dalam mendampingi anak belajar di rumah dan meningkatkan kemampuan peserta dalam mengasuh dan mendidik anak-anaknya. Kegiatan ini dimulai dengan ceramah dan dilanjutkan dengan diskusi dan penugasan. Penugasan yang dimaksud adalah dengan merancang aktifitas pendampingan belajar anak yang baik untuk seminggu.

(ii) Simulasi dan Pembimbingan

Dilaksanakan untuk memberikan kesempatan kepada orangtua untuk berlatih dalam menerapkan Pemahaman tentang perannya sebagai pendamping anak belajar (simulasi di rumah). Kegiatan ini secara khusus bertujuan untuk memberikan pengetahuan dan pemahaman yang komprehensif kepada orangtua tentang pentingnya memiliki kapasitas dan kemampuan dalam meningkatkan kemampuan seperti guru professional untuk membantu dan memahami karakteristik belajar anak. Beberapa kemampuan pedagogik yang dapat disimulasikan oleh orangtua dirumah adalah kemampuan dalam memahami peserta didik, mampu merancang pembelajaran, mampu melaksanakan pembelajaran, merancang dan melaksanakan evaluasi pembelajaran, dan mengembangkan peserta didik, juga berkaitan dengan bagaimana menciptakan pembelajaran yang menyenangkan di rumah. Dalam hal ini, orangtua dibekali pengetahuan dan keterampilan bagaimana merancang dan melaksanakan pendampingan yang baik demi menciptakan lingkungan belajar yang menyenangkan di rumah. Dengan demikian, pemahaman anak akan materi pelajaran lebih baik dan berimplikasi pada meningkatnya prestasi belajar anak.

\section{(iii) Penugasan}

Penugasan diberikan untuk mengetahui sejauhmana pemahaman dan penguasaan peserta pelatihan (orangtua) dalam menerapkan materi pelatihan yang diberikan terkait peranan orang tua dan cara menerapkan disiplin positif yang baik yang perlu dikuasai orangtua sebagai pendidik dan pengasuh anak. Penugasan yang dimaksud adalah praktek simulasi terkait merancang dan melaksanakan aktifitas pendampingan belajar yang mendukung terciptanya suasana belajar yang menyenangkan di rumah secara berkelompok, berupa menyusun rencana aktifitas pendampingan yang efektif dalam mendampingi anak belajar selama pandemi Covid-19. Simulasi tersebut akan di nilai oleh kelompok lain dan diakhir simulasi semua kelompok, tim pengabdi memberikan penilaian kepada masing-masing kelompok berupa penilaian kualitatif (masukan dan saran).

\section{Langkah-Langkah Kegiatan}

Langkah-langkah kegiatan yang dilakukan dalam kegiatan PPM ini dapat dilihat pada gambar tersebut:

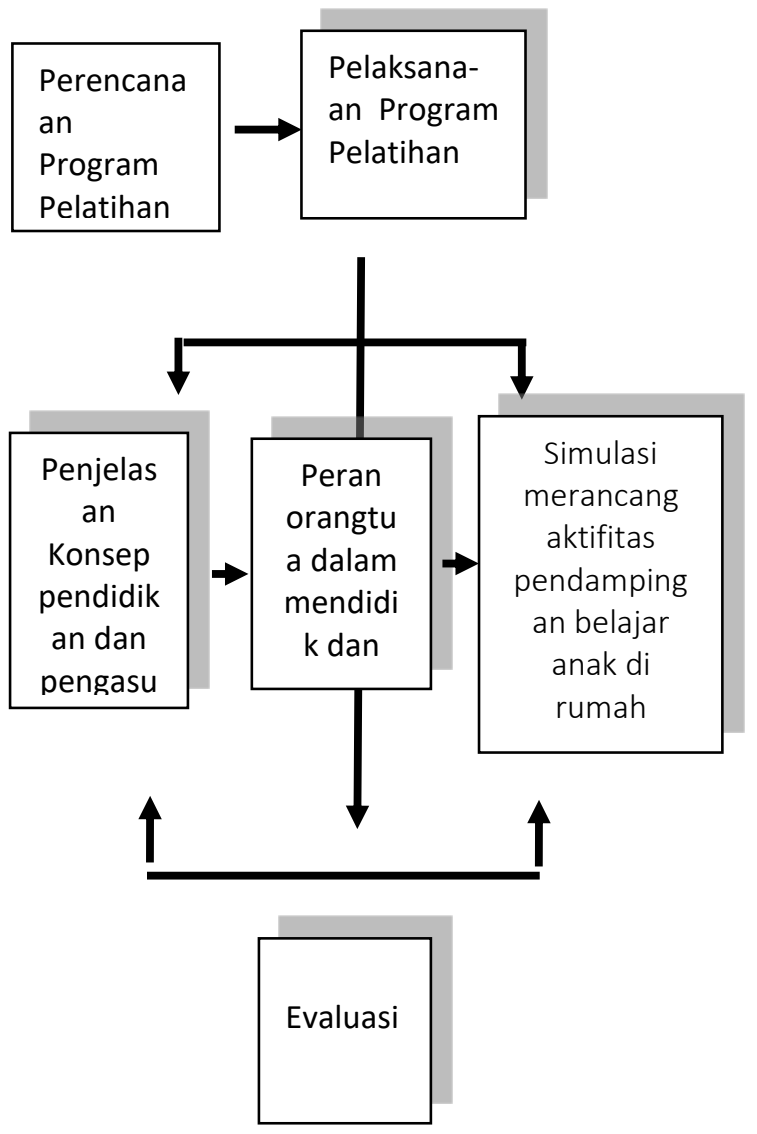

Bagan 1. Kerangka pemecahan masalah

Dari gambar kerangka pemecahan masalah tersebut di atas, dapat dilihat bahwa, proses pelatihan yang telah dilaksanakan kepada 
orangtua ini meliputi tiga komponen penting, yaitu:

(i) Perencanaan Program Pengabdian pada Masyarakat

Perencanaan dilakukan melalui serangkaian koordinasi antar anggota tim, yang meliputi rencana desain dan tujuan pelatihan; mengidentifikasi karakteristik peserta pelatihan, mulai dari tahap awal kegiatan hingga evaluasi kegiatan pelatihan.

(ii) Pelaksanaan Program Pengabdian pada Masyarakat

Pelaksanaan program kegiatan ini meliputi dua kegiatan utama, yakni penjelasan konsep terkait pendidikan dan pengasuhan anak, peranan orang tua dalam pendidikan dan pengasuhan anak, dan juga pentingnya penerapan disiplin positif dalam mendidik dan mengasuh anak.

(iii) Evaluasi Kegiatan PPM

Proses evaluasi kegiatan PPM dilakukan untuk menilai seluruh rangkaian kegiatan pelatihan yang telah dilakukan. Kegiatan evaluasi ini sangat signifikan untuk mengetahui ketercapaian program pengabdian kepada masyarakat yang telah dilaksanakan.

\section{Rancangan Evaluasi}

Keberhasilan dari program PPM Kelompok Dosen ini dapat dilihat dari:

1. Partisipasi orangtua selama mengikuti kegiatan.

2. Perhatian orangtua selama mengikuti kegiatan.

3. Pemahaman orangtua setelah mengikuti kegiatan.

4. Diskusi orangtua terkait peran pedagogik orangtua dalam mendidik dan mengasuh anak.

5. Respon dan antusiasme orangtua untuk mengimplementasikan hasil pelatihan yaitu melaksanakannya perannya dalam mendidik dan mengasuh anak seperti guru professional di rumah.

Penilaian dilakukan dengan menggunakan instrumen berupa lembar observasi dan angket yang dikembangkan oleh tim pengabdi. Selain itu, dilakukan pula observasi serta pembagian instrumen berupa angket yang diberikan kepada orangtua untuk memberikan penilaian terhadap pelaksanaan kegiatan pelatihan secara keseluruhan. Berikut ini adalah butir pernyataan di dalam angket yang dipergunakan oleh tim pengabdi dalam mengidentifikasi pemahaman awal dan akhir peserta pelatihan terhadap membelajarkan orangtua menjadi pendamping aktivitas belajar di rumah bagi anaknya saat pandemi Covid 19:

- Saya memahami dengan baik dan menyeluruh teknik mendidik dan mengasuh anak

- Saya memahami dengan baik dan menyeluruh terkait pentingnya mendisiplinkan anak belajar dengan baik

- Saya memahami dengan baik dan menyeluruh model dan manfaat disiplin positif bagi anak

- Saya memahami dengan baik pentingnya peranan orangtua dalam menjaga keseimbangan antara sikap, keterampilan dan pengetahuan untuk membangun soft skills dan hard skills anak.

- Saya mengetahui bahwa penting menerapkan konsep pendidikan komprehensif di rumah

- Saya mengetahui setidaknya 3 (tiga) manfaat disiplin positif bagi anak

- Saya mengetahui kunci keberhasilan hubungan sekolah-keluarga-komunitas menurut Epstein

- Saya menganggap bahwa peranan saya sebagai pendamping aktivitas belajar anak di rumah selama pandemi Covid 19 adalah sangat krusial bagi perkembangan mereka

- Saya memahami dengan baik bagaimana merancang program aktifitas yang dan efektif dalam mendampingi anak belajar selama pandemi Covid-19

- Saya mengalami kemudahan dalam merancang program aktifitas yang dan efektif dalam mendampingi anak belajar selama pandemi Covid-19

\section{HASIL DAN PEMBAHASAN \\ Hasil}

Program kegiatan PPM ini telah dilaksanakan selama 2 (dua) hari dan meliputi dua kegiatan utama, yakni penjelasan terkait 
pendapat para ahli terkait peranan peranan orangtua dalam perkembangan anak penting dilaksanakannya disiplin positif di rumah, penjelasan tentang pendidikan komprehensif, dan dilanjutkan dengan praktek simulasi merancang aktifitas pendampingan belajar anak yang menyenangkan di rumah. Kegiatan ini diikuti oleh 37 orang perwakilan dari para orangtua siswa dan guru TK dan SD di Kecamatan Gantiwarno, Kabupaten Klaten. Adapun daftar orangtua dan guru perwakilan sekolah yang hadir dideskripsikan dalam tabel berikut ini:

Tabel 1: Daftar Peserta Pelatihan

\begin{tabular}{|c|l|c|}
\hline No & \multicolumn{1}{|c|}{ Nama Sekolah } & Jumlah \\
\hline 1 & SD Kanisius Kerten & 1 \\
\hline 2 & SD Muhammadiyah Gantiwarno & 1 \\
\hline 3 & SD N 1 Baturan & 1 \\
\hline 4 & SD N 1 Gentan & 2 \\
\hline 5 & SD N 1 Jabung & 1 \\
\hline 6 & SD N 1 Karangturi & 1 \\
\hline 7 & SD N 1 Kerten & 1 \\
\hline 8 & SD N 1 Kragilan & 2 \\
\hline 9 & SD N 1 Mlese Gantiwarno & 1 \\
\hline 10 & SD N 2 Ceporan & 1 \\
\hline 11 & SD N 2 Jabung & 1 \\
\hline 12 & SD N 2 Jogoprayan & 1 \\
\hline 13 & SD N 2 Katekan & 1 \\
\hline 14 & SD N 2 Kragilan & 1 \\
\hline 15 & SD N 2 Mlese & 2 \\
\hline 16 & TK Al Amien & 19 \\
\hline \multicolumn{2}{|c}{ Total } & 37 \\
\hline
\end{tabular}

Pelaksanaan program pelatihan ini dilaksanakan secara daring selama 8 jam pelatihan dengan menggunakan aplikasi Zoom, yang dimulai sejak pukul 07.00wib sampai dengan pukul 15.00wib. Pukul 07.00wib, peserta pelatihan melakukan registrasi ulang kepada panitia penyelenggara. Pukul 08.00 wib kegiatan pelatihan dilaksanakan.

\section{Pelaksanaan Kegiatan}

a. Penjelasan dan pemahaman konsep

Kegiatan pelatihan ini dimulai dengan memberikan penjelasan kepada orangtua tentang peranan penting orangtua dalam pendidikan dan pengasuhan anak. Penjelasan ini disampaikan oleh Bapak Prof. Dr. Anik Gufton, M.Pd. bertujuan untuk memberikan pemahaman dan keterampilan secara teoritis dan praktis kepada orangtua terkait peranan orangtua dalam pendidikan anak melalui pendampingan, tentunya pengetahuan ini dapat dipergunakan serta diimplementasikan oleh orangtua untuk meningkatkan kualitas pembelajaran anak di rumah, khususnya selama pandemi Covid-19. Sehingga implikasi dari pelatihan terhadap keterlaksanaan proses pembelajaran anak di rumah dapat memberikan dampak langsung dan tidak langsung yang positif jika secara konsisten dilaksanakan dan mendampingi anak belajar menjadi bagian penting dari proses belajar anak.

Beberapa penjelasan terkait pentingnya peranan orangtua dalam pendampingan anak belajar ini juga direlevansikan dengan tips melaksanakan disiplin positif menurut Nelsen (2008). Kedua hal ini sangat signifikan untuk diketahui oleh orangtua mengingat peserta didik memiliki karakteristik yang berbedabeda. Dengan adanya pengetahuan orangtua terkait disiplin positif, maka diharapkan orangtua mampu memperlakukan anaknya dengan bermartabat dan saling menghormati, serta memiliki kepercayaan bahwa anak memiliki kemampuan untuk bekerja sama dan berkontribusi.

Pengabdi mengharapkan di akhir pelatihan ini para orangtua memiliki kepercayaan diri yang lebih tinggi dalam mendampingi dalam proses kegiatan belajar anak di rumah sehingga kualitas proses pembelajaran menjadi meningkat dengan demikian akan berdampak pula pada ketercapaian tujuan pembelajaran secara lebih optimal, efektif dan efisien.

Penyampaian materi dilengkapi dengan diskusi antara penyampai materi dengan para peserta, dimana dalam kegiatan diskusi orangtua diberikan kebebasan untuk menyampaikan pendapatnya dan menceritakan proses kegiatan pembelajaran yang selama ini mereka lakukan di rumah. Hal ini sangat diperlukan untuk menggali pemahaman orangtua terhadap pendampingan pembelajaran yang selama ini mereka pergunakan dan aplikasikan di rumah untuk membantu 
berlangsungnya proses belajar yang kondusif dan optimal. Pada sesi diskusi ini, tim pengabdi berfungsi sebagai fasilitator proses diskusi, hal ini bertujuan agar para orangtua dapat mengungkapkan lebih banyak kendala-kendala apa saja yang selama ini mereka hadapi ketika harus mengimplementasikan peran mereka sebagai pendamping dalam pembelajaran anak sehingga pembelajaran menjadi lebih optimal.

Sesi pada hari pertama ini ditutup dengan tanya jawab, agar peserta dapat langsung menanyakan hal-hal yang tidak mereka pahami kepada pemateri. Pada sesi tanya jawab ini para orangtua sangat antusias untuk bertanya, sebagian besar pertanyaan orangtua berhubungan dengan tips-tips praktis dalam mendorong anak belajar di era digital.

Setelah istirahat siang, para peserta kembali ke room Zoom untuk mengikuti kegiatan peer group. Pelaksanaan peer group bertujuan untuk membahas kembali apa yang telah disampaikan pada kegiatan sebelumnya. Dalam kegiatan ini peserta diminta secara berkelompok untuk mendiskusikan tentang peranan orangtua sebagai pelaksana disiplin positif di rumah. Hal ini bertujuan agar semua peserta dapat saling memberikan masukan dan saran pada apa yang akan disimulasikan oleh teman dalam kelompoknya. Kegiatan peer group didampingi oleh semua tim pengabdi. Orangtua yang mengalami kesulitan dapat bertanya dan/atau sharing secara langsung kepada penyelenggara program dan teman dalam satu tim mereka karena pada tahap ini fungsi tim pengabdi sama dengan pada tahap diskusi, yaitu hanya sebagai fasilitator bagi semua kelompok.

\section{Praktik dan proses pendampingan}

Pada hari kedua, sesi kegiatan difokuskan pada praktik simulasi penyusunan program kemitraan berupa penyusunan rancangan aktifitas pendampingan belajar anak untuk seminggu. Pada sesi ini, setiap kelompok diberikan waktu secukupnya terlebih dahulu untuk menyiapkan rancangan aktifitas pendampingan yang akan mereka simulasikan dalam bentuk tabel sesuai template yang telah disiapkan oleh tim pengabdi. Penyusunan rancangan kegiatan pendampingan belajar yang baik disusun dengan kreatif dan disesuaikan dengan karakter anak. Kemudian, setelah semua anggota kelompok menyusun rancangan aktifitas pendampingan belajar anak, maka dimulailah sesi sharing/berbagi dalam simulasi tersebut. Sesi sharing memegang kontribusi yang penting mengingat pada simulasi ini, setiap peserta harus benar-benar mendesign aktifitas pendampingan yang kreatif, sesuai dengan materi yang telah dipelajari, dan berdasarkan karakter anak. Masing-masing kelompok diberikan waktu selama kurang lebih 15 menit hingga 20 menit untuk membagikan kegiatan/aktifitas pembelajaran inovatif yang disusunnya.

Kelompok lain berperan sebagai pengamat atau observer yang kemudian memberi masukan terhadap kelompok yang maju saat itu. Setelah semua kelompok memperoleh giliran untuk membagikan kegiatan/aktifitas pembelajaran yang diperankannya, maka tiba giliran tim pengabdi secara bergantian memberikan saran dan masukan baik yang bersifat umum maupun khusus kepada kelompok-kelompok yang maju demi perbaikan dari rancangan kegiatan/aktifitas tersebut. Praktik dan proses pendampingan dalam penyusunan rancangan kegiatan/aktifitas ini berlangsung dari pukul 08.00 hingga pukul 13.00. Pada pukul 14 adalah kegiatan evaluasi bersama.

\section{Pembahasan}

Setelah program pelatihan selesai, diakhir hari kedua dilaksanakan evaluasi oleh peserta yang merupakan rangkaian terakhir dari kegiatan pelatihan yang dilakukan. Evaluasi pelatihan dilihat dari berbagai aspek. Aspek keberhasilan dari program PPM ini dapat dilihat dari:

1. Sikap dan motivasi orangtua selama mengikuti kegiatan

Berdasarkan hasil pengamatan, sebanyak $100 \%$ orangtua menunjukkan sikap sangat antusias selama mengikuti program pelatihan ini. Hal ini juga dapat dilihat dari semangat orangtua saat memberikan komentar atau bertanya kepada penyelenggara program. 
Motivasi yang tinggi juga terlihat pada sikap antusias orangtua saat menyusun rancangan aktifitas pendampingan dan semangat orangtua yang tinggi untuk mengikuti kegiatan pelatihan dari awal hingga akhir. Semua orangtua mengikuti program pelatihan secara menyeluruh, tidak ada satupun orangtua yang pamit meninggalkan pelatihan sebelum pelatihan selesai di selenggarakan. Selain itu, orangtua menunjukkan keinginan yang cukup besar untuk dapat mengaplikasikan rancangan aktifitas pembelajaran anak yang telah disimulasikan yang menurut mereka akan sangat membantu mencapai tujuan pembelajaran yang lebih optimal, selain itu juga para orangtua juga optimis bahwa penerapan materi terkait peranan orangtua dalam pendampingan anak belajar ini juga akan menciptakan proses belajar yang lebih dinamis, efektif dan menyenangkan bagi anak di rumah, khususnya selama pandemi Covid-19.

2. Pemahaman dan keterampilan orangtua setelah mengikuti kegiatan

Pemahaman orang mengalami peningkatan setelah mengikuti program pelatihan, hal ini ditunjukkan dengan sebesar 95\% orangtua mampu menyusun program kemitraan, yaitu rancangan aktifitas pendampingan belajar anak berdasarkan template tabel disediakan pengabdi. Sedangkan, keterampilan orangtua dalam pelatihan ini dilihat dari kemampuan orangtua dalam mendesain rancangan aktifitas pembelajaran anak yang kreatif dan sesuai dengan karakter anak, serta mampu memberikan masukan dan tips bagi teman lain. Hal ini merupakan pencapaian yang cukup signifikan dari para orangtua, antusiasme, dan sikap positif yang ditunjukkan tentu saja cukup berkontribusi secara signifikan terhadap keterampilan orangtua dalam penyusunan rancangan dan selanjutnya mengimplementasikan rancangan tersebut di rumah masing-masing.

\section{Faktor Pendukung dan Penghambat Kegiatan}

Pelaksanaan program kegiatan PPM ini secara umum telah terselenggara dengan baik. Beberapa faktor pendukung yang berkontribusi terhadap keberhasilan kegiatan PPM ini adalah:

1. Pihak UPT Dinas Pendidikan Kecamatan Gantiwarno, terkait dengan diberikannya ijin bagi pengabdi sehingga PPM ini dapat terselenggara.

2. Pihak sekolah, terkait dengan dukungannya terhadap proses perijinan PPM ini sehingga proses perijinan dapat berjalan sangat cepat ditentukan dan disepakati. Serta dukungannya dengan memfasilitasi waktu dan mengundang orangtua untuk turut serta berparitisipasi dalam program PPM ini. Serta partisipasi dari guru, kepala sekolah dan pengawas sekolah cukup tinggi, sehingga sangat memperlancar terlaksananya kegiatan ini. Keterlibatan sebanyak 1 TK dan 15 SD dalam kegiatan ini cukup membuktikan tingginya partisipasi peserta pelatihan dalam kegiatan ini.

3. Tim pelaksana program PPM yang solid dan kompak, dari mulai persiapan sampai akhir kegiatan PPM ini, sehingga sangat memperlancar kegiatan ini.

4. Dukungan Fakultas Ilmu Pendidikan dalam berbagai aspek terutama dukungan dana sehingga pelaksanaan program PPM ini dapat berlangsung lancar atau tidak ditemui kendala-kendala yang berarti.

5. Sedangkan faktor penghambat yang terjadi dalam kegiatan PPM ini adalah kegiatan dilaksanakan secara online sehingga proses pendampingan orangtua menjadi cukup terbatas.

\section{PENUTUP}

Berdasarkan hasil paparan pembahasan kegiatan PPM Pelatihan membelajarkan orangtua menjadi pendamping aktivitas belajar di rumah bagi anaknya saat pandemi covid-19 ini, maka dapat disimpulkan bahwa:

1. Kegiatan peningkatan pengetahuan, wawasan para orangtua tentang bagaimana mendampingi aktivitas belajar anak di 
rumah dapat ditempuh melalui kegiatan pelatihan dengan menggunakan metode pelatihan/penyuluhan, Tanya-jawab, diskusi dan simulasi. Hal ini dimaksudkan agar pengetahuan yang didapat tidak hanya sebatas pengetahuan belaka tetapi peserta pelatihan langsung dapat mempraktikan pemahamannya tersebut.

2. Kegiatan pelatihan ini telah menghasilkan program kemitraan yaitu rancangan aktifitas pendampingan belajar anak yang dapat dipergunakan orangtua untuk meningkatkan kualitas pembelajaran anak di rumah dan juga meningkatkan kemampuan orangtua dalam mendampingi anak belajar sehingga pembelajaran menjadi lebih menyenangkan.

\section{DAFTAR PUSTAKA}

Aba Firdaus Al-Halwani. 1996. Melahirkan anak saleh. Yogyakarta: LeKAPIM.

Direktorat Pembinaan PAUD. 2017. Booklet Layanan Pendidikan dan Pengasuhan. Jakarta: Ditjen PAUD dan Dikmas.

Imam Musbikin. 2006. Mendidik anak kreatif ala Einstein. Yogyakarta: Mitra Pustaka. 